\title{
AS CONTROVÉRSIAS ACERCA DO DIREITO SUBJETIVO NO DIREITO ROMANO
}

\section{THE CONTROVERSIES ON SUBJECT LAW IN ROMAN LAW}

Resumo: A forma como se apresenta a problemática do direito subjetivo no Direito Romano e as críticas que lhe acompanham ainda hoje não encontram solução comum, entretanto, os debates redundaram na concentração e limitação do jus a uma única situação jurídica subjetiva: a do direito subjetivo. Pretende-se com esse ensaio abordar as controvérsias teóricas sobre a concepção romana (ou não) do direito subjetivo.

Palavras-chave: Jus. Romanitas. Corpus Juris Civilis.

Abstract: The way in which the problem of subjective law in Roman law is presented and the criticisms that accompany it still do not find a common solution, however, the debates have resulted in the concentration and limitation of the jus to a single subjective juridical situation: that of the subjective right. This essay intends to address the theoretical controversies about the Roman conception (or not) of the subjective right.

Keywords: Roman Law, Corpus Juris Civilis.

\footnotetext{
i Doutor em Direito Civil pela Universidade do Estado do Rio de Janeiro - UERJ (2005), Doutor em Ciências Ambientais e Florestais pela Universidade Federal Rural do Rio de Janeiro - UFRRJ (2015), Professor na Universidade Federal do Estado do Rio de Janeiro - UNI-RIO e Desembargador no Tribunal Regional da $2^{a}$ Região (Rio de Janeiro e Espírito Santo).
} 
Efetivamente, a morte do corpo social e econômico que o havia forjado implicou o recuo do Direito Romano. Nós somos herdeiros do Direito Romano (Roma communisnostrapatria est). Em uma grande proporção somos os heredes necessarii do Direito Romano: não esteve nunca em nossas mãos poder impedir que o Direito Romano fosse um elemento básico na formação da moderna civilização ocidental. Diz a máxima romana que o que é herdeiro uma vez é herdeiro sempre (heressemper, non potest desistere esse heres) e, em razão disso não podemos modificar o fato de que, por necessidade e por eleição, o Direito Romano haja desempenhado um grande papel na formação de nossa civilização e, por tudo, é demasiado tarde para se repudiar a hereditas, ainda que isso resulte em danos.

Objeção a que se poderia levantar seria a vantagem que se teria com a apreciação dos valores romanos. A resposta é que a História ou simplesmente a experiência exige a valoração dos elementos culturais. Uma valoração do legado do Direito Romano tem alcance prático a respeito da questão concreta de até que ponto vale a pena considerá-lo desde como disciplina universitária até o mais amplo interesse do seu estudo.

Por sermos os grandes herdeiros de uma tradição, parte dessa herança espiritual (a Romanitas) dever ser cuidadosamente guardada e cultivada, ou até mesmo, no possível, ter suas arestas aparadas. O Direito Romano existe ainda hoje não como passado, e sim como um presente: é um modelo; existe pela sua importância para a Ciência do Direito; e o nosso não se compõe senão de pensamentos todos romanos; existe não por assim ter requerido e autorizado o legislador, mas pela força da convicção científica.

A questão que devemos examinar é se vamos compreendê-lo, porque sem os méritos de seu vigor técnico, o seu estudo continuado é que se justifica por duas vezes. Em primeiro lugar, a histórica nos facilita um exemplo único do método jurídico do desenvolvimento legal, não de uma simples lei positiva, senão de um direito existente e de sua coordenação e desenvolvimento por meio da razão. Podemos observar este método na forma em que as idéias fundamentais da propriedade, do contrato e do direito subjetivo, expressadas primeiramente em um tosco conjunto de costumes, se converteram mediante processo através de muitos séculos, em um corpo consistente de doutrina razoável que, em suas linhas essenciais, não tenha sido criado pelo Estado, senão sancionando com sua proteção. 
No primeiro sentido, o estudo do Direito Romano é interessante não só como preparação para o trabalho profissional, senão como forma de inculcar o verdadeiro conceito de direito e de evolução jurídica. Em segundo lugar, o Direito Romano, em sua forma final, tal como apareceu no Corpus Juris de Justiniano ${ }^{1}$, constituiu, em seu ressurgimento, a base do moderno Direito Brasileiro. Este é a mera afirmação de um fato, verdadeiro em si mesmo, qualquer que seja nosso critério sobre a veneração medieval pelo Direito Civil. E isto faz do Direito Romano um tema de importância primordial para a história da Idade Média e da Época Moderna. Uma incursão histórico-teorética sobre o surgimento do Direito Romano significará nos permitir a sua continuidade.

A forma como se apresenta a problemática do direito subjetivo no Direito Romano e as críticas que lhe acompanham ainda hoje não encontram solução comum, entretanto, os debates redundaram na concentração e limitação do jus a uma única situação jurídica subjetiva: a do direito subjetivo. Mas, se a controvérsia desemboca na discussão da existência ou não do direito subjetivo no Direito Romano, magistralmente defendida por seus adeptos, haveria que indagar da centralização ou esgotamento do termo jus no Direito Subjetivo. É possível desvelar desse fenômeno outras figuras ainda ocultas? De um jus ancorado no direito subjetivo é limitado a essa certeza ou o jus poderia expressar manifestações de outras situações como a do interesse legítimo? Eis a vexata quaestio!'2, asseguram aos jurisdicionados.

\section{OBRAS CONSULTADAS}

GRANT, Michael. História de Roma. Trad. Waltensir Dutra. Rio de Janeiro: Civilização Brasileira, 1987.

VALLE, Gabriel. Dicionário Latim-Português. São Paulo: Thonson, 2004.

MONIER, Raymond Manuel. Élementaire de Droit Romain. 6. ed. Aalem: ScentiaVerlag, 1977.

1 Disponível em: <https://nacoesunidas.org/wp-content/uploads/2015/10/agenda2030-pt-br.pdf> Acesso em: 4 fev. 2018.

2 Disponível em: <https://nacoesunidas.org/wp-content/uploads/2015/10/agenda2030-pt-br.pdf> Acesso em: 4 fev. 2018. 
GIORDANI, Mário Curtis. A importância do Direito Romano é parte presente em toda a literatura específica: por todos: Direito Romano, 3. ed., Rio de Janeiro: Lumen Juris, 1996.

VOLTERRA, Edoardo. Istituzioni di Diritto Privato Romano. Roma: Edizioni Ricerche, 1961.

DA SILVA, Luiz Antonio Vieira. História Interna do Direito Romano Privado. Rio de Janeiro: Eduardo \& Enrique Laemert, 1854. 